ISSN 1392-3196 / e-ISSN 2335-8947

Zemdirbyste-Agriculture, vol. 107, No. 3 (2020), p. 195-202

DOI $10.13080 /$ z-a.2020.107.025

\title{
Soil physical state as influenced by long-term reduced tillage, no-tillage and straw management
}

\author{
Vaida STEPONAVIČIENĖ, Vaclovas BOGUŽAS, Aušra SINKEVIČIENĖ, Lina SKINULIENĖ, \\ Alfredas SINKEVIČIUS, Evaldas KLIMAS \\ Vytautas Magnus University \\ K. Donelaičio 58, Kaunas, Lithuania \\ E-mail: vaida.steponaviciene@vdu.lt
}

\begin{abstract}
Since 1999, a long-term field experiment has been done at the Experimental Station of the Lithuanian University of Agriculture (currently - Vytautas Magnus University). The current research was conducted in 2013-2015. The aim of the study was to evaluate the effects of long-term tillage systems and straw management on soil penetration resistance, shear strength and soil aggregate stability. The soil of the experimental site was Epieutric Endocalcaric Endogleyic Planosol. A short crop rotation was introduced: winter wheat $\rightarrow$ spring barley $\rightarrow$ spring oilseed rape. According to two factor field experiment, the straw was removed from one part of the experimental field, and on the other part of the field the straw was chopped and spread at harvesting (factor A). Six tillage systems: conventional (deep) and shallow ploughing, shallow loosening, shallow rotovating, catch cropping and rotovating, and no-tillage, were used as a subplot (factor B). During a 16-year (1999-2015) period, long-term application of reduced tillage resulted in a significant increase in soil penetration resistance and shear strength. The results of current study show that the lesser the tillage depth, the higher the soil penetration resistance and shear strength. The effect of straw residue spreading was lower comparing with treatment without straw.

Soil aggregate stability was highly dependent on tillage. Shallow rotovating before sowing increased soil aggregate stability by up to 1.8 times, incorporation of plant residues of white mustard into the soil by a rotovator before sowing increased it by up to 2.0 times and no-tillage by up to 1.9 times, compared with conventional ploughing.
\end{abstract}

Key words: shear strength, soil aggregate stability, soil penetration resistance.

\section{Introduction}

Sustainable agricultural practices are crucial for the maintenance and improvement of soil functions. The long-term implementation of crop rotation and tillage influences the soil environment through inputs and disturbance of the soil, which, in turn, impact soil quality. Tillage has long-term impacts on the agroecosystems. Conservation tillage systems with minimal soil disturbance, including no- or reduced-tillage and residue retention or mulching, are thus often proposed as a means to improve agricultural sustainability. Reduced tillage has positive impacts on soil properties (Moraru, Rusu, 2013).

Conservation agriculture comes with a set of principles to implementation and development of sustainable technologies with the aim of retaining sufficient quantities of vegetal remains on the soil surface for soil protection against erosion, water evaporation and surface leakage, for better use of rainfall and improvement of physical, chemical and biological soil properties associated with long-term stable yield (Rusu, Moraru, 2015). Karlen et al. (2019) have noted that awareness of and interest in soil health has increased exponentially in the last decade. They proposed that excessive tillage is a major factor in the connection between the decline in soil health and degradation, i.e. erosion. Wilson et al. (2019) identified indicators of soil physical quality in a long-term no-tillage and showed that subsequent tillage so dramatically changed the soil physical properties of the surface that they were no longer valid soil quality indicators.

Positive effects on soil porosity and aggregate stability across a wide range of soil types and climates are attributable to conservation tillage systems (Moraes et al., 2016; Gao et al., 2017). However, the beneficial influence of conservation tillage practices, such as no or reduced soil disturbance, cover cropping and residue retention on soil physical properties and soil organic matter apparently rely on site-specific interactions, postadoption period, climate conditions, the properties of the former management system and the choice of cover crop species (Hubbard et al., 2013; Derpsch et al., 2014).

No-tillage technology has many advantages for economic and environmental protection, and it is currently used on 117 million ha worldwide and 1.15 million ha in Europe (López et al., 2012; Romaneckas et al., 2015).

Please use the following format when citing the article:

Steponavičienė V., Bogužas V., Sinkevičienė A., Skinulienė L., Sinkevičius A., Klimas E. 2020. Soil physical state as influenced by longterm reduced tillage, no-tillage and straw management. Zemdirbyste-Agriculture, 107 (3): 195-202. DOI 10.13080/z-a.2020.107.025 
Feiza et al. (2010) and Velykis and Satkus (2018) have reported that tillage and crop rotation are fundamental factors that influence soil quality and sustainability of cropping systems, soil physical properties depend on tillage intensity and soil depth.

Bogužas et al. (2010) have documented that the aggregate structure of soil did not change significantly with different tillage technologies. The most significant increases in soil aggregates stability were recorded at $>1 \mathrm{~mm}$ (on average, $74.3 \%$ and $96.3 \%$ ) and $>0.25 \mathrm{~mm}$ (on average, $14.6 \%$ and $20.3 \%$ ) in the shallow loosening or untilled soil (no-tillage) treatments, compared with conventionally ploughed soil at the beginning of vegetation. Similar tendencies were found at the end of plant vegetation, but the influence of tillage decreased.

Soil quality is also determined by soil hardness. Soil penetration resistance is influenced by soil density, structure, moisture as well as by the aggregate size. The smaller the diameter of the soil aggregates, the higher the hardness of the soil. Soil hardness increases with increasing soil density as the moisture content decreases (Feiza et al., 2008). Higher soil hardness was obtained by no-tillage, compared with deep and shallow ploughing. The hardness of the topsoil $(0-10 \mathrm{~cm})$ immediately after sowing was similar to that in shallow ploughing and deep ploughing treatments, while it was $49-54 \%$ higher in directly drilled soil. After harvesting, the hardness was the lowest in the soil, where deep ploughing had been used. It was $12-30 \%$ higher in shallow ploughing and $52-71 \%$ higher in no-tillage treatments, compared with the soil of conventional (deep) ploughing (Feiza et al., 2008; Feizienè et al., 2009). Soil strength is affected by soil water content, bulk density and clay content (or texture) of the soil (Guerif, 1994; Chung et al., 2013).

Tillage and rotation are fundamental factors influencing soil quality, crop performance and thus the sustainability of cropping systems. Conservation tillage is considered one of the most effective management practices to obtain mutual benefits in terms of erosion control, carbon sequestration and reduced input of energy and labour (Ball et al., 1994; Morris et al., 2010). Decreased soil physical quality, in terms of excessive compaction of the untilled topsoil, is regarded as one of the primary reasons for yield reductions (Ball et al., 1994). This is especially problematic on weakly structured soils in humid temperate climates (Munkholm et al., 2003; 2013; Ball et al., 2007).

The aim of the study was to evaluate the effect of long-term tillage systems and straw management on soil penetration resistance, shear strength and soil aggregate stability.

\section{Materials and methods}

Description of the site, the soil and the experimental design. Since 1999, a long-term field experiment has been done at the Experimental Station $\left(54^{\circ} 52^{\prime} 50 \mathrm{~N}, 2^{\circ} 49^{\prime} 41 \mathrm{E}\right)$ of the Lithuanian University of Agriculture (currently - Vytautas Magnus University). Research was carried out during the period of 20132015 in the long-term field experiment. The soil of the experimental site was Epieutric Endocalcaric Endogleyic Planosol (Endoclayic, Aric, Drainic, Humic, Episiltic) according to the WRB (2014) (Table 1). The long-term experiment was laid out in a split-plot design with four replications and a total of 48 plots. The initial plot size was $102 \mathrm{~m}^{2}(6 \times 17 \mathrm{~m})$, and the harvested plot size was $30 \mathrm{~m}^{2}(15 \times 2.0 \mathrm{~m})$.
Table 1. Soil site characteristics $(0-20 \mathrm{~cm})$

\begin{tabular}{lc}
\hline \multicolumn{1}{c}{ Variable } & Mean value \\
\hline Sand \% & 33.7 \\
Clay \% & 16.0 \\
Silt \% & 50.3 \\
$\mathrm{pH}_{\mathrm{KCl}}$ & 7.6 \\
${\text { Buk density } \mathrm{Mg} \mathrm{m}^{3}}$ & $1.45-1.57$ \\
\hline
\end{tabular}

Study object was soil physical properties. The spring oilseed rape (Brassica napus L.), winter wheat (Triticum aestivum L.) and spring barley (Hordeum vulgare L.) were grown in the experiment.

According to two-factor field experiment, straw (factor A) was removed (R) from one part of the experimental field (control), and on the other part of the field the straw was chopped and spread (S) at harvest. Factor B - 6 different tillage systems investigated as subplots: 1) conventional (deep) ploughing (CP) at 23$25 \mathrm{~cm}$ depth in autumn (control), 2) shallow ploughing (SP) at $10-12 \mathrm{~cm}$ depth in autumn, 3) shallow loosening (SL) with sweep cultivator and disc harrow at 8-10 cm depth in autumn, 4) shallow rotovating (SR) at 5-6 cm depth before next crop sowing, 5) catch cropping and rotovating $(\mathrm{CCR})$ at $5-6 \mathrm{~cm}$ depth before next crop sowing, and 6) no-tillage (NT). White mustard (Sinapis alba L.) was undersown as a catch crop in the stubble only in catch cropping plots shortly after winter wheat and spring barley harvesting.

In 2013-2015, for ploughing, a plough PP-343 (Lithuania) with semi-helical shell boards, a chisel cultivator KLG-3.6 (Lithuania) and a disc harrow Väderstad Carrier 300 (Sweden) were used. Pre-sowing tillage was performed with a complex cultivator KLG3.6. The crops were sown by a pneumatic no-tillage machine Väderstad Rapid 300C Super XL (Sweden). Mineral fertilizers were incorporated at sowing. Weeds were controlled by spray application using a sprayer Amazone UF-901 (UK). The crops were harvested by a plot combine Wintersteiger Delta (Austria).

In 2013, before spring oilseed rape sowing, the plots of no-tillage treatment were sprayed with a systemic herbicide Roundap (a.i. glyphosate $480 \mathrm{~g} \mathrm{~L}^{-1}$ ) at a rate of 4.0 $\mathrm{L} \mathrm{ha}^{-1}$. The spring oilseed rape 'Fenja' was sown on 2 May at a seed rate of $4.50 \mathrm{~kg} \mathrm{ha}^{-1}$ and a sowing depth of $2 \mathrm{~cm}$. Placement fertilization with $\mathrm{N}_{16} \mathrm{P}_{16} \mathrm{~K}_{16}$ at $300 \mathrm{~kg} \mathrm{ha}^{-1}$ was applied at sowing. After sowing, herbicide Brasan $1 \mathrm{~L} \mathrm{ha}^{-1}$ (a.i. dmetachlor $500 \mathrm{~g} \mathrm{~L}^{-1}, 47.5 \%$ + clomazone $40 \mathrm{~g} \mathrm{~L}^{-1}, 4 \%$ ) was applied. At the beginning of flowering, the crop was sprayed with a broad-spectrum, systemic fungicide Folicur $1 \mathrm{~L} \mathrm{ha}^{-1}$ (a.i. tebuconazole $250 \mathrm{~g} \mathrm{~L}^{-1}$, includes N, N-dimethyldecanamide). Spring oilseed rape was harvested on 9 August.

In 2013, winter wheat 'Ada' was sown on 10 September at a seed rate of $200 \mathrm{~kg} \mathrm{ha}^{-1}$. At sowing, placement application of $\mathrm{N}_{9} \mathrm{P}_{15} \mathrm{~K}_{28}+\mathrm{S}_{6} 300 \mathrm{~kg} \mathrm{ha}^{-1}$ was performed. At winter wheat 2-3 leaf stage, the crop stand was sprayed with the herbicide Legacy Pro $2 \mathrm{~L} \mathrm{ha}^{-1}$ (a.i. $40 \mathrm{~g} \mathrm{~L}^{-1}$ diflufenican, $300 \mathrm{~g} \mathrm{~L}^{-1}$ pendimethalin $+250 \mathrm{~g} \mathrm{~L}^{-1}$ chlorotoluron).

In 2014, after resumption of vegetation, on 14 March, the crop was fertilized with ammonium nitrate $\mathrm{N}_{41} 120 \mathrm{~kg} \mathrm{ha}^{-1}$. Two weeks later, $\mathrm{N}_{44} 130 \mathrm{~kg} \mathrm{ha}^{-1}$ was applied. Winter wheat was harvested on 29 July.

In 2015, before spring barley sowing, the plots of no-tillage treatment were sprayed with Roundap 4.0 $\mathrm{L} \mathrm{ha}^{-1}$ (a.i. glyphosate $480 \mathrm{~g} \mathrm{~L}^{-1}$ ). Spring barley 'KVS 
Orphelia' was sown at a seed rate of $170 \mathrm{~kg} \mathrm{ha}^{-1}, \mathrm{~N}_{16} \mathrm{P}_{16} \mathrm{~K}_{16}$ $300 \mathrm{~kg} \mathrm{ha}^{-1}$ was applied at sowing. After emergence of dicotyledonous weeds, the herbicide Mustang (a.i. aminopyralid $10 \mathrm{~g} \mathrm{~L}^{-1}+$ florasulam $5 \mathrm{~g} \mathrm{~L}^{-1}+2.4 \mathrm{D}$ $180 \mathrm{~g} \mathrm{~L}^{-1}$ ) was applied. At the tillering stage, the crop was additionally applied with ammonium nitrate $\mathrm{N}_{41} 120 \mathrm{~kg}$ $\mathrm{ha}^{-1}$. After the first symptoms of diseases had appeared on leaves, the crop was sprayed with the fungicide Bumper (a.i. propiconazole $250 \mathrm{~g} \mathrm{~L}^{-1}$ ). At flag leaf stage, the spring barley crop was additionally fertilized with ammonium nitrate $\mathrm{N}_{44} 100 \mathrm{~kg} \mathrm{ha}^{-1}$ and sprayed with the fungicide Amistar $0.60 \mathrm{~L} \mathrm{ha}^{-1}$ (a.i. azoxystrobin $250 \mathrm{~g} \mathrm{~L}^{-1}$ ). Spring barley was harvested on 12 August.

Soil sampling and soil aggregate stability analysis. Soil properties of the experimental site were determined in 2013 and 2015 experimental years. Soil samples were collected for aggregate stability analysis at $0-10$ and $10-25 \mathrm{~cm}$ depths of the plough layer from 10 spots of each plot. Then the samples were composited (250 g per sample) to give a representative plot sample for each depth. The soil was air-dried and then sieved into eight size fractions $<0.25,0.25-0.5,0.5-1.0,1.0-2.0$, $2.0-4.0,4.0-5.6,5.6-8.0$ and $>8.0 \mathrm{~mm}$ diameter using a sieve shaker (Retsch $\mathrm{GmbH}$, Germany). Aggregate stability of soil was determined at $0-10$ and $10-25 \mathrm{~cm}$ depths by using a wet sieving apparatus (Eijkelkamp Agrisearch Equipment, The Netherlands). The air-dried soil aggregates (1-2 mm size) are wet sieved in distilled water and then stable aggregates are destroyed by $0.2 \%$
$\left(\mathrm{NaPO}_{3}\right)_{6}$ solution, oven-dried at $105^{\circ} \mathrm{C}$ for $24 \mathrm{~h}$ and weighed (Al-Kaisi et al., 2014).

Shear strength was measured using a penetrometer Geonor 72410 (Eijkelkamp) at $0-10$ and $10-25 \mathrm{~cm}$ depths of the plough layer after sowing or resumption of winter wheat vegetation in 10 spots per plot. Soil penetration resistance was measured using a penetrologger 06.15SA (Eijkelkamp) at 5, 10, 15, 20, $25,30,35,40,45$ and $50 \mathrm{~cm}$ depths after sowing of spring oilseed rape and spring barley or resumption of winter wheat vegetation in 10 spots per plot.

Meteorological conditions. The climate of Lithuania is moderately warm, transitioning from maritime to continental. Lithuania is in a cool temperate zone with moderately warm summers and moderately cold winters. According to the climate zoning, Kaunas region belongs to the middle lowland zone of Lithuania, the sub-region of the lower-reaches of the river Nemunas. Meteorological conditions were described by using the data from Kaunas Meteorological Station (Fig. 1).

In the first half of April, 2013 the weather was winter-cold, with temperatures in most areas dropping to $-7-14^{\circ} \mathrm{C}$ (Fig. 1, 2013). The highest temperature in April was $18-23^{\circ} \mathrm{C}$, while the average monthly temperature was $5.5^{\circ} \mathrm{C}$, i.e. $1.2^{\circ} \mathrm{C}$ lower than the long-term average. Warm weather came in May, but at the beginning of the month frosts were still up to $-3^{\circ} \mathrm{C}$ with the highest monthly temperatures rising to $27-31^{\circ} \mathrm{C}$. The average temperature in May was $16.6^{\circ} \mathrm{C}$, i.e. $4^{\circ} \mathrm{C}$ higher than the long-term
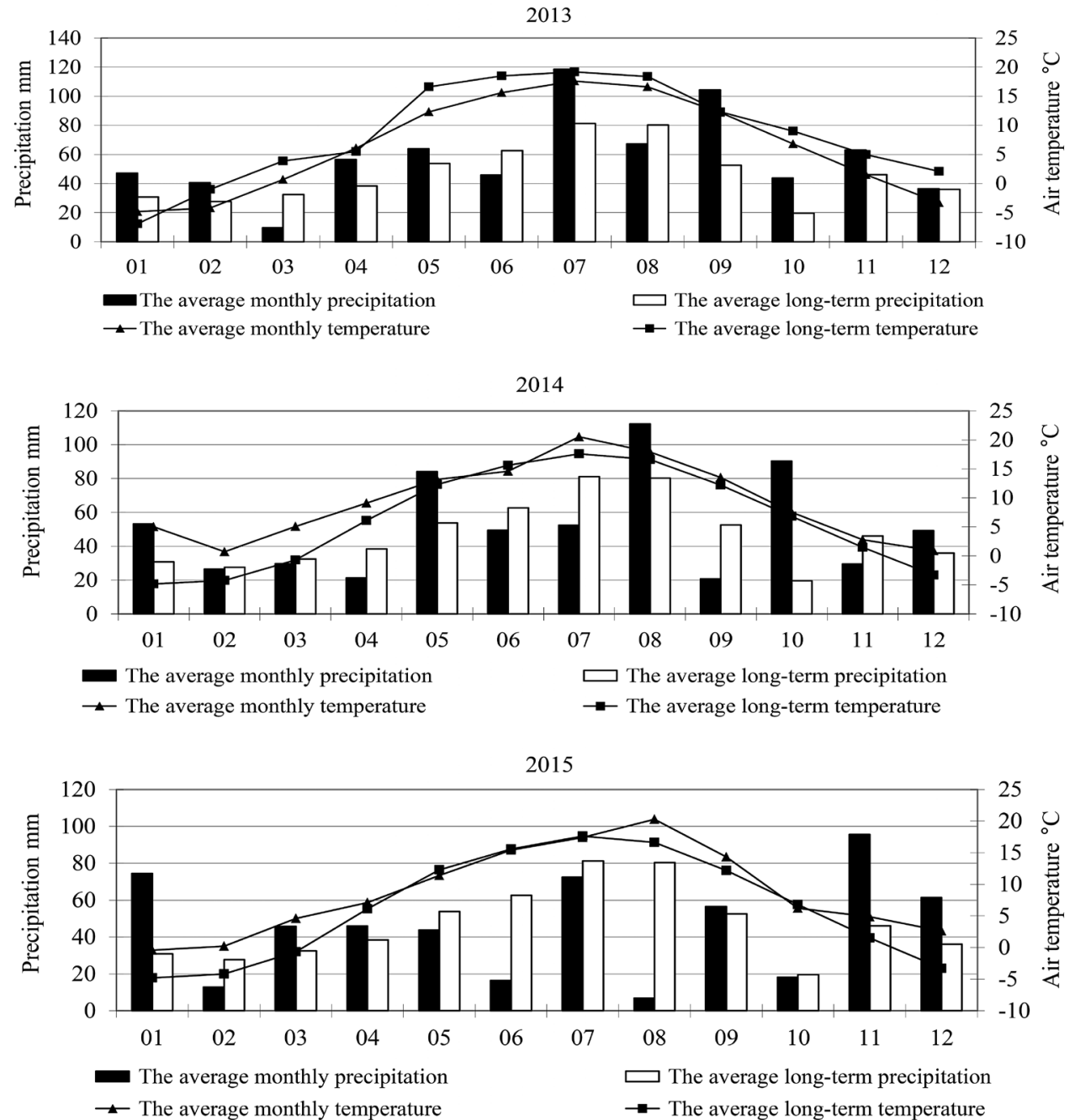

Figure 1. Meteorological conditions in 2013-2015 (data of Kaunas Meteorological Station) 
average. Total rainfall in May was $63.8 \mathrm{~mm}$, i.e. $16.5 \mathrm{~mm}$ higher than the average long-term rainfall. In addition, there was some hail. In June, July and August, very warm and moderately humid weather prevailed. The average temperature was almost the same as in June $\left(19.2^{\circ} \mathrm{C}\right)$, i.e. $1.6^{\circ} \mathrm{C}$ higher than the long-term average.

In 2013, the period of winter wheat sowing had the average temperatures of $12^{\circ} \mathrm{C}$ and very rainy weather, with the rainfall exceeding the long-term average more than twice. Warm and humid weather was favourable for germination of winter wheat. October was warmer than the long-term average with the average temperatures ranging from $7^{\circ} \mathrm{C}$ to $7.5^{\circ} \mathrm{C}$ and lower than the long-term average (43 $\mathrm{mm})$ rainfall.

The average temperature in November exceeded the long-term average by $4^{\circ} \mathrm{C}$, while the rainfall did not significantly differ from the long-term average $(20 \mathrm{~mm})$. December was warmer than average. The average temperature in January was low, but normal (Fig. 1, 2014). The average monthly temperature in February was positive $\left(1^{\circ} \mathrm{C}\right)$, and the precipitation was low at $22 \mathrm{~mm}$. The temperature in March was quite high, compared with the long-term average $\left(5^{\circ} \mathrm{C}\right.$ and $-2^{\circ} \mathrm{C}$, respectively), while the precipitation was $24 \mathrm{~mm}$. In early April, wheat vegetation resumed as the air temperature rose. In terms of rainfall, April was dry with $20 \mathrm{~mm}$ of rainfall per month. The average temperature in May was $13^{\circ} \mathrm{C}$, close to the long-term average of $12^{\circ} \mathrm{C}$. May was quite rainy with $81 \mathrm{~mm}$ of rainfall, i.e. $16 \mathrm{~mm}$ more than the long-term average. June was $2^{\circ} \mathrm{C}$ colder than the long-term average $\left(16^{\circ} \mathrm{C}\right)$ with the average monthly temperature of $14^{\circ} \mathrm{C}$ and only about $10 \mathrm{~mm}$ of rainfall (long-term average was $50 \mathrm{~mm}$ ). July was significantly warmer than usual, with the average monthly temperature of $20^{\circ} \mathrm{C}$ (longterm average was $17^{\circ} \mathrm{C}$ ) and low rainfall, especially at the end of the month $(50 \mathrm{~mm}$, compared with a long-term average of $80 \mathrm{~mm}$ ). The beginning of August was very dry, with warm and dry weather prevailing for weeks. As the heat receded, it began to rain and the average monthly rainfall was $110 \mathrm{~mm}$.

The average monthly temperature in April, 2015 was $0.2^{\circ} \mathrm{C}$ higher than the long-term average, while the average monthly rainfall was $4.7 \mathrm{~mm}$ higher than the long-term average (Fig. 1, 2015). In May, the average temperature was $11.4^{\circ} \mathrm{C}$, i.e. $1.8^{\circ} \mathrm{C}$ lower than the longterm average. The average rainfall this month was $43.8 \mathrm{~mm}$, which was as much as $17.9 \mathrm{~mm}$ less than the long-term average. In June, conditions were unfavourable for crop growth and emergence of weeds. The average temperature in July was $1.3^{\circ} \mathrm{C}$ lower than the long-term average, and the rainfall exceeded the long-term average (72.4 and $24.2 \mathrm{~mm}$, respectively). August was warm but very dry with an average monthly temperature of $20.3^{\circ} \mathrm{C}$, i.e. $3^{\circ} \mathrm{C}$ higher than the long-term average. Rainfall in August was also very low; the monthly average only reached $6.9 \mathrm{~mm}$, which was $82 \mathrm{~mm}$ less than the longterm average.

Statistical analysis. All experimental data were processed using a two-factor analysis of variance (ANOVA) according to Leonavičienè (2007) from the statistical software package SYSTAT, version 10 (SPSS Inc., USA). The significance of differences among the treatments was estimated by the least significant difference (LSD) test. If there was a significant difference between a specific treatment and the control treatment, its probability level is indicated as follows: * - when $P \leq$ $0.050>0.010$ (significant at 95\% probability level), ** - when $P \leq 0.010>0.001$ (significant at $99 \%$ probability level), *** - when $P \leq 0.001$ (significant at $99.99 \%$ probability level).

\section{Results and discussion}

Soil penetration resistance. In 2013, spreading of straw did not have significant effect on the soil penetration resistance at the depth of $0-50 \mathrm{~cm}$ (Table 2). Tillage systems exerted a significant impact on soil penetration resistance. For spring oilseed rape crop, soil penetration resistance significantly increased after applying shallow ploughing $(27.5-46.0 \%)$ at the depth of $10-25 \mathrm{~cm}$, shallow loosening with a sweep cultivator and disc harrow in the autumn $(27.4-46.9 \%)$ at the depth of $5-20 \mathrm{~cm}$, shallow rotovating $(20.8-61.1 \%)$ at the depths of 5-25 and $45-50 \mathrm{~cm}$, catch cropping and rotovating in spring and no-tillage at the depth of $5-25 \mathrm{~cm}-20.8-$ $66.4 \%$ and $23.5-64.6 \%$ respectively, compared with conventional ploughing.

Table 2. Soil penetration resistance after spring oilseed rape sowing in 2013

\begin{tabular}{ccccccccccc}
\hline \multirow{2}{*}{ Treatment Soil penetration resistance MPa at different depths cm } \\
\cline { 2 - 11 } & 5 & 10 & 15 & \multicolumn{8}{c}{20} & 25 & 30 & 35 & 40 & 45 & 50 \\
\hline \multicolumn{10}{c}{ Straw retention (factor A) } \\
\hline R (control) & 1.49 & 1.63 & 1.60 & 1.65 & 1.80 & 2.11 & 2.49 & 2.71 & 2.94 & 2.80 \\
S & 1.54 & 1.69 & 1.65 & 1.64 & 1.70 & 2.08 & 2.27 & 2.64 & 2.79 & 2.92 \\
\hline \multicolumn{10}{c}{ Tillage system (factor B) } \\
\hline CP (control) & 1.09 & 1.13 & 1.17 & 1.24 & 1.49 & 1.98 & 2.42 & 2.57 & 2.52 & 2.58 \\
SP & 1.30 & $1.59^{* * *}$ & $1.62^{* * *}$ & $1.81^{* * *}$ & $1.90^{* *}$ & 2.15 & 2.27 & 2.40 & 2.59 & 2.56 \\
SL & $1.56^{* * *}$ & $1.66^{* * *}$ & $1.60^{* * *}$ & $1.58^{* *}$ & 1.68 & 2.16 & 2.30 & 2.67 & 2.80 & 2.96 \\
SR & $1.65^{* * *}$ & $1.82^{* * *}$ & $1.80^{* * *}$ & $1.79^{* * *}$ & $1.80^{*}$ & 2.00 & 2.44 & 2.96 & $3.45^{* *}$ & $3.30^{*}$ \\
CCR & $1.72^{* * *}$ & $1.88^{* * *}$ & $1.84^{* * *}$ & $1.75^{* * *}$ & $1.80^{*}$ & 2.14 & 2.45 & 2.86 & 2.94 & 3.10 \\
NT & $1.77^{* * *}$ & $1.86^{* * *}$ & $1.71^{* * *}$ & $1.70^{* * *}$ & $1.84^{*}$ & 2.14 & 2.40 & 2.57 & 2.82 & 2.67 \\
\hline
\end{tabular}

Factor A: R - straw removed, S - straw chopped and spread; factor B: CP - conventional ploughing, SP - shallow ploughing, $\mathrm{SL}$ - shallow loosening, $\mathrm{SR}$ - shallow rotovating, $\mathrm{CCR}$ - catch cropping and rotovating, NT - no-tillage; differences significant at $*-P \leq 0.05>0.01, * *-P \leq 0.01>0.001$ and *** $-P \leq 0.001$; Fisher LSD test $v s$ control

In 2014, straw spreading for winter wheat crop had a significant effect on soil penetration resistance at the depth of $15-35 \mathrm{~cm}$, where it was $6.7-13.8 \%$ higher, compared with the treatment without straw (Table 3). The effect of tillage systems was even more obvious.
Soil penetration resistance significantly increased after applying shallow ploughing at the depth of $15-35 \mathrm{~cm}$ (17.9-22.5\%), shallow loosening with a sweep cultivator and a disc harrow at the depth of $10-45 \mathrm{~cm}(15.8-45.5 \%)$, shallow rotovating in spring at the depth of $5-35 \mathrm{~cm}$ 
Table 3. Soil penetration resistance after resumption of winter wheat vegetation in 2014

\begin{tabular}{|c|c|c|c|c|c|c|c|c|c|c|}
\hline \multirow{2}{*}{ Treatment } & \multicolumn{10}{|c|}{ Soil penetration resistance MPa at different depths $\mathrm{cm}$} \\
\hline & 5 & 10 & 15 & 20 & 25 & 30 & 35 & 40 & 45 & 50 \\
\hline \multicolumn{11}{|c|}{ Straw retention (factor $\mathrm{A}$ ) } \\
\hline $\mathrm{R}$ (control) & 2.42 & 2.78 & 2.60 & 2.39 & 2.39 & 2.39 & 2.54 & 2.79 & 3.06 & 3.05 \\
\hline $\mathrm{S}$ & 2.46 & 2.92 & $2.86^{*}$ & $2.72 * * *$ & $2.67 * * *$ & $2.61 * * *$ & $2.71 *$ & 2.91 & 3.34 & 3.31 \\
\hline \multicolumn{11}{|c|}{ Tillage system (factor B) } \\
\hline $\mathrm{CP}$ (control) & 1.85 & 2.08 & 2.00 & 1.96 & 2.01 & 2.13 & 2.35 & 2.59 & 2.85 & 3.11 \\
\hline SP & 2.05 & 2.29 & $2.45^{*}$ & $2.58 * * *$ & $2.64 * * *$ & $2.67 * * *$ & $2.77 * * *$ & 2.83 & 2.98 & 3.07 \\
\hline SL & 2.23 & $2.96^{* * *}$ & $2.91 * * *$ & $2.68 * * *$ & $2.61 * * *$ & $2.66^{* * *}$ & $2.74 * *$ & $3.00 *$ & $3.41 *$ & 3.12 \\
\hline $\mathrm{SR}$ & $2.78 * * *$ & $3.38 * * *$ & $3.08 * * *$ & $2.8 * * *$ & $2.6^{* * *}$ & $2.59 * * *$ & $2.65^{*}$ & 2.91 & 3.37 & 3.39 \\
\hline CCR & $2.78 * * *$ & $3.21 * * *$ & $2.99 * * *$ & $2.6^{* * *}$ & $2.53 * * *$ & $2.46^{*}$ & 2.59 & $2.96^{*}$ & 3.32 & 3.20 \\
\hline NT & $2.94 * * *$ & $3.18^{* * *}$ & $2.97 * * *$ & $2.72 * * *$ & $2.52 * * *$ & $2.49 *$ & $2.66^{*}$ & 2.83 & 3.26 & 3.20 \\
\hline
\end{tabular}

Explanations under Table 2

(12.8-62.5\%), catch cropping and rotovating in spring at the depths of 5-30 and $40 \mathrm{~cm}(14.3-54.3 \%)$ and notillage at the depth of 5-35 cm (13.2-58.9\%), compared with conventional ploughing.

In 2015, straw spreading for spring barley did not have a significant influence $(P>0.05)$ on soil penetration resistance (Table 4).
Soil penetration resistance significantly increased after applying shallow rotovating at the depth of 5-20 cm (78.7-96.1\%), catch cropping and rotovating in spring at the depth of 5-20 cm $(57.4-87.4 \%)$ and notillage at the depth of 5-20 cm (56.6-77.2\%), compared with conventional ploughing.

Table 4. Soil penetration resistance after spring barley sowing in 2015

\begin{tabular}{|c|c|c|c|c|c|c|c|c|c|c|}
\hline \multirow{2}{*}{ Treatment } & \multicolumn{10}{|c|}{ Soil penetration resistance MPa at different depths $\mathrm{cm}$} \\
\hline & 5 & 10 & 15 & 20 & 25 & 30 & 35 & 40 & 45 & 50 \\
\hline \multicolumn{11}{|c|}{ Straw retention (factor $\mathrm{A})$} \\
\hline $\mathrm{R}$ (control) & 1.72 & 1.93 & 1.91 & 1.92 & 1.99 & 2.23 & 2.46 & 2.58 & 2.78 & 2.73 \\
\hline $\mathrm{S}$ & 1.72 & 1.95 & 1.90 & 1.90 & 1.96 & 2.25 & 2.43 & 2.75 & 2.90 & 3.02 \\
\hline \multicolumn{11}{|c|}{ Tillage system (factor B) } \\
\hline $\mathrm{CP}$ (control) & 1.17 & 1.27 & 1.28 & 1.36 & 1.68 & 2.14 & 2.14 & 2.71 & 2.67 & 2.70 \\
\hline $\mathrm{SP}$ & 1.30 & 1.59 & 1.62 & 1.81 & 1.90 & 2.15 & 2.27 & 2.41 & 2.59 & 2.56 \\
\hline SL & 1.56 & 1.66 & 1.60 & 1.58 & 1.68 & 2.16 & 2.30 & 2.67 & 2.87 & 2.96 \\
\hline SR & $2.10 * *$ & $2.49 * *$ & $2.49 * *$ & $2.43 * *$ & 2.31 & 2.34 & 2.60 & 2.99 & 3.39 & 3.16 \\
\hline CCR & $2.15 * *$ & $2.38 * *$ & $2.27 *$ & $2.14^{*}$ & 2.12 & 2.31 & 2.36 & 2.49 & 2.57 & 2.92 \\
\hline NT & $2.06 * *$ & $2.25^{*}$ & $2.17 *$ & $2.13 *$ & 2.17 & 2.34 & 2.54 & 2.70 & 2.95 & 2.94 \\
\hline
\end{tabular}

Explanations under Table 2

According to Kadžienè et al. (2007), the threshold for soil hardness, when the roots of plants cannot penetrate into the soil, is considered critical. It depends on the plants cultivated as well as on the soil texture. The critical threshold for hardness is $2-3.6 \mathrm{MPa}$. When examining the hardness of soil after sowing or after resumption of winter wheat vegetation, the following tendency was observed in reduced tillage systems: the deeper the layer and the higher the hardness of soil regardless of the reduced tillage system.

Alvarez and Steinbach (2009) also found that application of a reduced tillage system caused an increase in soil bulk density (at the $0-20 \mathrm{~cm}$ depth) and cone penetration resistance, in comparison with the conventional ploughing. In Lopez-Garrido et al. (2014) investigations, at the time of seedling emergence, repeated no-tillage represented the highest soil penetration resistance of the upper layer (6.04 MPa), compared with reduced tillage $(0.65 \mathrm{MPa})$ and conventional ploughing $(0.40 \mathrm{MPa})$. The adverse effects of soil disturbance produced by the tillage are minimized with minimum and no-tillage systems, some soil properties related to soil compaction progressively increase in these systems. The effect of tillage practices on soil physical properties depends on both the type of implement used and the soil conditions (Özgöz et al., 2007; Alesso et al., 2019).

Shear strength. When no-tillage was applied, the soil characteristics, that are closely related, change.
As one characteristic changes, so do the others (LopezGarrido et al., 2014).

The research results in 2014 and 2015 might have been significantly influenced by warmer than usual climatic conditions and a shortage of humidity. This might have exerted significant effect on the critical threshold of soil penetration resistance. In 2013, at the beginning of spring oilseed vegetation, the effect of tillage systems on shear strength of soil was significant both in the upper $0-10 \mathrm{~cm}$ and the bottom $10-25 \mathrm{~cm}$ layers (Fig. 2). Compared with conventional ploughing, all the rest of the tillage systems significantly increased the shear strength of soil.

In 2014, which was drier than 2013, at the beginning of winter wheat vegetation, the soil shear strength at $0-10 \mathrm{~cm}$ layer was significantly $11.6 \%$ higher and at a deeper layer $10-25 \mathrm{~cm}$ it was $11.1 \%$ higher in the soil with straw, compared with the soil without straw (Fig. 3). The effect of tillage systems was significant in both $0-10$ and $10-25 \mathrm{~cm}$ soil layers. Compared with conventional ploughing, in the treatments of other tillage systems the shear strength of soil increased in the upper $0-10 \mathrm{~cm}$ layer from $14.6 \%$ to $64.5 \%$ and in the deeper $10-25 \mathrm{~cm}$ layer from $49.8 \%$ to $71.7 \%$.

In 2015 , the shear strength of soil was measured only in the upper 0-10 cm layer (Fig. 4), because May had less rainfall than usual. Due to the lack of moisture, the soil was too hard to make measurements. The monthly 


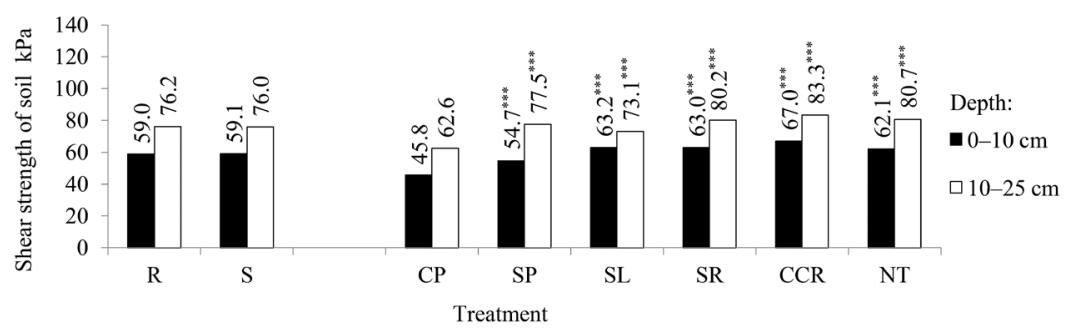

Explanations under Table 2

Figure 2. Shear strength of soil after spring oilseed rape sowing in 2013

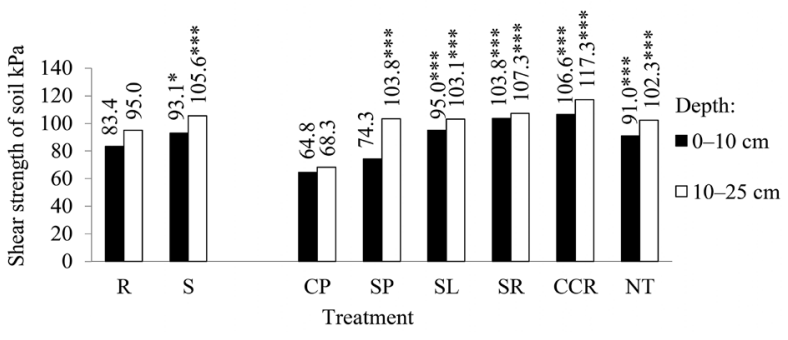

Explanations under Table 2

Figure 3. Shear strength of soil after resumption of winter wheat vegetation in 2014

rainfall in May averaged $43.8 \mathrm{~mm}$, which was $17.9 \mathrm{~mm}$ less than the long-term average. The effect of tillage on shear strength in the upper $0-10 \mathrm{~cm}$ soil layer was significantly higher (by 12.9\%) in shallow rotovating, in catch cropping and rotovating in spring (by 14\%) and in no-tillage (by $11.3 \%$ ) treatments, compared with conventional ploughing.

Comparison of the three-year data with the research results obtained by Alvarez and Steinbach (2009) revealed similar tendencies - shallow cultivation with a rotary cultivator before sowing, shallow rotovating in spring, no-tillage with direct drilling as well as the use of straw significantly increased the shear strength of soil. According to research carried out on sandy loam soils by the Lithuanian Research Centre for Agriculture and Forestry in Akademija, Kedainiai district, the best physical properties of soil (density, shear strength and air permeability) were determined by conventional (deep) ploughing. Significantly poorer soil physical properties were found in no-tillage system. In the conditions of possible global warming, no-tillage helps to conserve the moisture content in the upper soil layer after sowing and during the early stages of plant growth (Feiziene et al., 2007; 2008; Feiza et al., 2010).

A summary of the data of the three experimental years suggests that a long-term application of reduced tillage results in a marked increase in soil penetration resistance as well as shear strength. The lesser was the depth of the tillage, the higher was the soil penetration resistance and shear strength. The effect of straw spreading on soil penetration resistance and shear strength was determined only in drier and hotter year of 2014.

Soil aggregate stability. Soil structure is the aggregates of various sizes and shapes of mineral and organic granulometric elements (soil clumps). Good soil structure coupled with the choice of appropriate tillage ensures the yield (Bogužas et al., 2010). Hou et al. (2013) reported that the amount of macro-aggregate fraction decreased with conventional tillage practices in the $0-20$ depth. This decreasing of $>0.25 \mathrm{~mm}$ aggregate fraction in the soil with conventional tillage could be mainly due

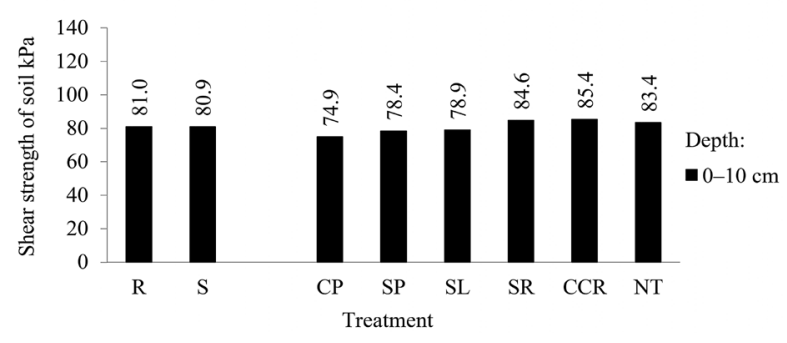

Explanations under Table 2

Figure 4. Shear strength of soil after spring barley sowing in 2015

to the mechanical disruption of soil structure macroaggregates from frequent tillage operations and reduced aggregate stability.

Type of soil has a great influence on the tillage practices to be applied. Reduced tillage diminishes the risk of moisture loss and maintains proper temperature, which is very important in shaping the seedbed. Due to various factors, soil structure may be degraded for mechanical, physical, biological or chemical reasons. Mechanically, the structure is dismantled by cultivating the soil, driving or raining. Soil structure decomposes and as calcium is leached from the upper layers, and the quantity of humus decreases. Soil stable aggregates lose adhesive and begin to decompose. Soil degradation should be controlled and efforts should be made to enrich the soil with organic matter (Morris et al., 2010; Soane et al., 2012).

Research results from year 2013 showed that soil aggregate stability was significantly higher in the $0-10 \mathrm{~cm}$ layer when the treatments of shallow rotovating before sowing, catch cropping and rotovating in spring and no-tillage were applied, compared with conventional ploughing 1.8, 2 and 1.9 times, respectively (Fig. 5). In the $10-25 \mathrm{~cm}$ layer, a significant increase in soil aggregate stability was determined: in shallow rotovating before sowing 1.4 times, in catch cropping and rotovating in spring 1.4 times and in no-tillage 1.4 times, compared with conventional ploughing. Straw spreading did not have significant influence on soil aggregate stability.

Data from 2015 showed significantly higher soil aggregate stability in the $0-10 \mathrm{~cm}$ layer in the treatments of shallow rotovating before sowing, catch cropping and rotovating in spring and no-tillage, compared with conventional ploughing by $30.5,37.1$ and 34.2 percentage points, respectively (Fig. 6).

A significant increase in soil aggregate stability was determined in the 10-25 cm layer as well: in the treatment of shallow rotovating before sowing 21.8 percentage points, catch cropping and rotovating in spring 20.5 percentage points and in no-tillage 18.7 percentage points, compared with conventional ploughing. Soil 


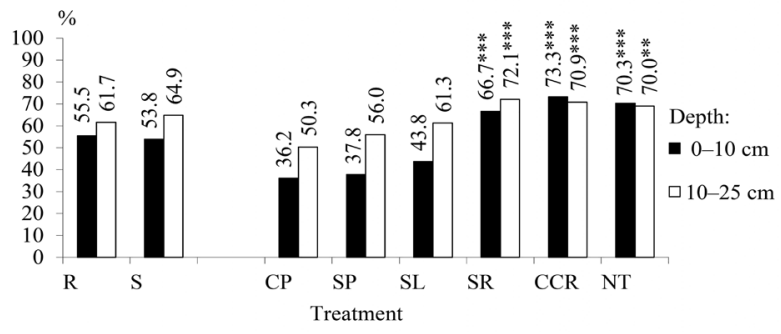

Explanations under Table 2

Figure 5. Soil aggregate stability after spring oilseed rape sowing in 2013

aggregate stability is the lowest if the soil is annually deeply or shallowly ploughed, and incorporation of straw residues has a tendency to increase aggregate stability. Similar trends were found in the research conducted by Bogužas et al. (2010) and Velykis and Satkus (2018). Notillage has a positive effect on soil structure, significantly reducing the amount of small aggregates and increasing the amount of stable aggregates not only in the upper $0-10 \mathrm{~cm}$ layer but also in the $10-25 \mathrm{~cm}$ layer. Al-Kaisi et al. (2014) have found that an increase in large aggregates in untilled soils is the result of the presence of large quantity of crop residue on the soil surface and minimum soil disturbance, which facilitates soil structural stability.

\section{Conclusions}

During a 16-year (1999-2015) period of field experiments, the following long-term changes in soil physical state occurred:

1. Long-term application of reduced tillage resulted in a significant increase in soil penetration resistance and shear strength. It was found that the lesser the depth of the tillage, the higher the soil penetration resistance and shear strength. The effect of straw retention was lower comparing with treatment without straw.

2. Soil aggregate stability was highly dependent on the tillage. Shallow rotovating before sowing increased soil aggregate stability by up to 1.8 times, while incorporation of plant residues of white mustard into the soil by a rotovator before sowing increased it by up to 2 times and no-tillage - by up to 1.9 times, compared with conventional (deep) ploughing.

3. Soil aggregate stability was the lowest when the soil was deeply or shallowly ploughed every year, while the incorporation of plant residues tended to increase soil aggregate stability. In the upper 0-10 and $10-25 \mathrm{~cm}$ layers, reduced tillage and no-tillage had a positive effect on soil aggregate stability.

\section{Acknowledgements}

This work was supported by the National Science Program "The effect of long-term, different-intensity management of resources on the soils of different genesis and on other components of the agro-ecosystems" (grant No. SIT-9/2015) funded by the Research Council of Lithuania.

Received 16092019

Accepted 02042020

\section{References}

1. Alesso C. A., Masola M. J., Carrizo M. E., Cipriotti P. A., Imhoff S. D. 2019. Spatial variability of short-term effect of tillage on soil penetration resistance. Archives of Agronomy and Soil Science, 65 (6): 822-832.

https://doi.org/10.1080/03650340.2018.1532076

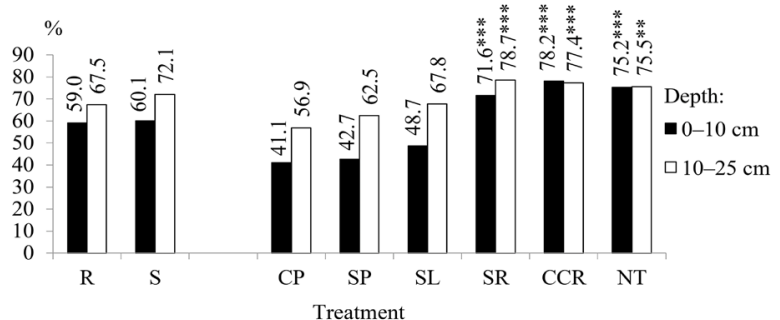

Explanations under Table 2

Figure 6. Soil aggregate stability after spring barley sowing in 2015

2. Al-Kaisi M. M., Douelle A., Kwaw-Mensah D. 2014 Soil microaggregate and macroaggregate decay over time and soil carbon change as influenced by different tillage systems. Journal of Soil and Water Conservation, 69 (6): 574-580. https://doi.org/10.2489/jswc.69.6.574

3. Alvarez R., Steinbach H. S. 2009. A review of the effects of tillage systems on some soil physical properties, water content, nitrate availability and crops yield in the Argentine Pampas. Soil and Tillage Research, 104 (1): 1-15. https://doi.org/10.1016/j.still.2009.02.005

4. Ball B. C., Lang R. W., Robertson E. A. G., Franklin M. F. 1994. Crop performance and soil conditions on imperfectly drained loams after 20-25 years of conventional tillage or direct drilling. Soil and Tillage Research, 31 (2-3): 97-118. https://doi.org/10.1016/0167-1987(94)90074-4

5. Ball B. C., Batey T., Munkholm L. J. 2007. Field assessment of soil structural quality - a development of the Peerlkamp test. Soil use and Management, 23 (4): 329-337. https://doi.org/10.1111/j.1475-2743.2007.00102.x

6. Bogužas V., Kairytė A., Jodaugienė D. 2010. Soil physical properties and earthworms as affected by soil tillage systems, straw and green manure management. ZemdirbysteAgriculture, 97 (3): 3-14.

7. Chung S. O., Sudduth K. A., Motavalli P. P., Kitchen N. R. 2013. Relating mobile sensor soil strength to penetrometer cone index. Soil and Tillage Research, 129: 9-18.

https://doi.org/10.1016/j.still.2012.12.004

8. Derpsch R., Franzluebbers A. J., Duiker S. W., Reicosky D. C., Koeller K., Friedrich T., Sturny W. G., Sá J. C. M., Weiss K. 2014. Why do we need to standardize no-tillage research? Soil and Tillage Research, 137: 16-22.

https://doi.org/10.1016/j.still.2013.10.002

9. Feiza V., Feiziené D., Kadžienė G. 2008. Agro-physical properties of Endocalcari-Epihypogleyic Cambisol arable layer in long-term soil management systems. Žemès ūkio mokslai, 15 (2): 13-23.

10. Feiza V., Feizienè D., Auškalnis A., Kadžienė G. 2010. Sustainable tillage: results from long-term field experiments on Cambisol. Zemdirbyste-Agriculture, 97 (2): 3-14.

11. Feiziené D., Feiza V., Lazauskas S., Kadžienè G., Šmanskaite D., Deveikyte I. 2007. The influence of soil management on soil properties and yield of crop rotation. Zemdirbyste-Agriculture, 94 (3): 129-145.

12. Feizienė D., Feiza V., Kadžienė G., Šlepetienė A. 2008. Endocalcari-Epihypogleyic Cambisol plough layer quality in long-term soil management systems. Žemès ūkio mokslai, 15 (2): 1-12 (in Lithuanian).

13. Feizienè D., Feiza V., Kadžienè G. 2009. The influence of meteorological conditions on soil water vapour exchange rate and $\mathrm{CO}_{2}$ emission under different tillage systems. Zemdirbyste-Agriculture, 96 (2): 3-22 (in Lithuanian).

14. Gao L., Becker E., Liang G., Houssou A. A., Wu H., Wu X., Cai D., Degré A. 2017. Effect of different tillage systems on aggregate structure and inner distribution of organic carbon. Geoderma, 288: 97-104. https://doi.org/10.1016/j.geoderma.2016.11.005

15. Guerif J. 1994. Effects of compaction on soil strength parameters. Soane B. D., van Ouwerkerk C. (eds). Soil compaction in crop production. Developments in Agricultural Engineering, vol. 11, chapter 9, p. 191-214. https://doi.org/10.1016/B978-0-444-88286-8.50017-9 
16. Hou X., Li R., Jia Z., Han Q. 2013. Effect of rotational tillage on soil aggregates, organic carbon and nitrogen in the Loess Plateau Area of China. Pedosphere, 23 (4): 542-548. https://doi.org/10.1016/S1002-0160(13)60047-8

17. Hubbard R. K., Strickland T. C., Phatak S. 2013. Effects of cover crop systems on soil physical properties and carbon/ nitrogen relationships in the coastal plain of south-eastern USA. Soil and Tillage Research, 126: 276-283. https://doi.org/10.1016/j.still.2012.07.009

18. Kadžienė G., Feiza V., Feizienè D., Šimanskaite D., Ramanauskienè B. 2007. Soil moisture and penetration dynamics using different tillage systems. Vagos, 77 (30): 13-18 (in Lithuanian).

19. Karlen D. L., Veum K. S., Sudduth K. A., Obrycki J. F., Nunes M. R. 2019. Soil health assessment: past accomplishments current activities and future opportunities. Soil and Tillage Research, 195: 104365. https://doi.org/10.1016/j.still.2019.104365

20. Leonavičienè T. 2007. SPSS programu paketo taikymas statistiniuose tyrimuose. Vilnius, p. 61-67 (in Lithuanian).

21. López M. V., Blanco-Moure N., Limón M. Á., Gracia R. 2012. No tillage in rainfed Aragon (NE Spain): effect on organic carbon in the soil surface horizon. Soil and Tillage Research, 118: 61-65. https://doi.org/10.1016/j.still.2011.10.012

22. Lopez-Garrido R., Madejon E., Leon-Camacho M., Giron I., Moreno F., Murillo J. M. 2014. Reduced tillage as an alternative to no-tillage under Mediterranean conditions: a case study. Soil and Tillage Research, 140: 40-47. https://doi.org/10.1016/j.still.2014.02.008

23. Moraes M. T. D., Debiasi H., Carlesso R., Franchini J. C., Silva V. R. D., Luz F. B. D. 2016. Soil physical quality on tillage and cropping systems after two decades in the subtropical region of Brazil. Soil and Tillage Research, 155: 351-362. https://doi.org/10.1016/j.still.2015.07.015

24. Moraru P. I., Rusu T. 2013. No-tillage and minimum tillage systems with reduced energy consumption and soil conservation in the hilly areas of Romania. Journal of Food, Agriculture and Environment, 11 (2): 1227-1231.

25. Morris N. L., Miller P. C. H., Orson J. H., FroudWilliams R. J. 2010. The adoption of non-inversion tillage systems in the United Kingdom and the agronomic impact on soil, crops and the environment - a review. Soil and Tillage Research, 108 (1-2): 1-15.

https://doi.org/10.1016/j.still.2010.03.004

26. Munkholm L. J., Schjønning P., Rasmussen K. J., Tanderup K. 2003. Spatial and temporal effects of direct drilling on soil structure in the seedling environment. Soil and Tillage Research, 71 (2): 163-173.

https://doi.org/10.1016/S0167-1987(03)00062-X

27. Munkholm L. J., Heck R. J., Deen B. 2013. Long-term rotation and tillage effects on soil structure and crop yield. Soil and Tillage Research, 127: 85-91. https://doi.org/10.1016/j.still.2012.02.007

28. Özgöz E., Akbaş F., Çetin M., Erşahin S., Günal H. 2007. Spatial variability of soil physical properties as affected by different tillage systems. New Zealand Journal of Crop and Horticultural Science, 35: 1-13. https://doi.org/10.1080/01140670709510162

29. Romaneckas K., Šarauskis E., Avižienytė D., Buragienè S., Arney D. 2015. The main physical properties of planosol in maize (Zea mays L.) cultivation under different longterm reduced tillage practices in the Baltic region. Journal of Integrative Agriculture, 14 (7): 1309-1320. https://doi.org/10.1016/S2095-3119(14)60962-X

30. Rusu T., Moraru P. I. 2015. Impact of climate change on crop land and technological recommendations for the main crops in Transylvanian Plain, Romania. Romanian Agricultural Research, 32: 103-111.

31. Soane B. D., Ball B. C., Arvidsson J., Basch G., Moreno F., Roger-Estrade J. 2012. No-till in northern, western and south-western Europe: a review of problems and opportunities for crop production and the environment. Soil and Tillage Research, 118: 66-87. https://doi.org/10.1016/j.still.2011.10.015

32. Velykis A., Satkus A. 2018. The impact of tillage, Caamendment and cover crop on the physical state of a clay loam soil. Zemdirbyste-Agriculture, 105 (1): 3-10. https://doi.org/10.13080/z-a.2018.105.001

33. Wilson G. V., Wells R. R., Dabney S. M., Zhang T. 2019. Filling an ephemeral gully channel: impacts on physical soil quality. Catena, 174: 164-173. https://doi.org/10.1016/j.catena.2018.11.006

34. WRB. 2014. World reference base for soil resources. World Soil Resources Reports No. 106. FAO, p. 187-189. https://doi.org/10.1016/j.catena.2018.11.006

ISSN 1392-3196 / e-ISSN 2335-8947

Zemdirbyste-Agriculture, vol. 107, No. 3 (2020), p. 195-202

DOI 10.13080/z-a.2020.107.025

\title{
Dirvožemio fizikinė būklė po ilgalaikio supaprastinto bei bearimio žemès dirbimo ir šiaudụ panaudojimo
}

\author{
V. Steponavičienė, V. Bogužas, A. Sinkevičienė, L. Skinulienė, A. Sinkevičius, E. Klimas \\ Vytauto Didžiojo universitetas
}

\section{Santrauka}

1999 m. Lietuvos žemės ūkio universiteto (dabar - Vytauto Didžiojo universitetas) Bandymų stotyje įrengtas stacionarus ilgalaikis lauko eksperimentas. Tyrimas atliktas 2013-2015 metais. Eksperimento tikslas - jvertinti ilgalaikio žemès dirbimo ir šiaudų panaudojimo įtaką dirvožemio kietumui, šlyties pasipriešinimui ir dirvožemio trupinėlių patvarumui. Tyrimo vietos dirvožemis - giliau glejjiškas pasotintasis palvažemis. Taikyta tokia žemės ūkio augalų sèjomaina: žieminiai kviečiai $\rightarrow$ vasariniai miežiai $\rightarrow$ vasariniai rapsai. Vienoje eksperimentinio laukelio dalyje šiaudai pašalinti, kitoje susmulkinti ir paskleisti (A veiksnys). Ir fone be šiaudų, ir fone su paskleistais šiaudais tirtos 6 žemės dirbimo sistemos (B veiksnys). Po 16 eksperimento vykdymo (1999-2015) metu taikant mažesnio intensyvumo žemės dirbimo sistemą labai padidejjo dirvožemio kietumas ir šlyties pasipriešinimas. Tyrimo rezultatai parodė, kad kuo mažesnis žemès dirbimo gylis, tuo kietesnis dirvožemis ir didesnis šlyties pasipriešinimas. Taip pat nustatyta, kad augalinių liekanų paskleidimo poveikis buvo mažesnis lyginat su variantu, kuriame augalinės liekanos buvo pašalintos. Dirvožemio trupinėlių struktūros patvarumas labai priklausė nuo žemės dirbimo intensyvumo. Palyginus su giliuoju arimu, paviršinis purenimas rotoriniu kultivatoriumi prieš sèją ji padidino 1,8 karto, baltuju garstyčių žalioji trąša, ịterpta rotoriniu kultivatoriumi prieš sèją, -2 kartus, o ilgą laiką nedirbtoje dirvoje šis rodiklis padidèjo 1,9 karto.

Reikšminiai žodžiai: dirvožemio kietumas, dirvožemio trupinèlių struktūros patvarumas, šlyties pasipriešinimas. 